\title{
池田欣史 学位論文審査要旨
}

$\begin{array}{ccccc}\text { 主查 } & \text { 清 } & \text { 水 } & \text { 英 } & \text { 治 } \\ \text { 副主查 } & \text { 福 } & \text { 本 } & \text { 宗 } & \text { 嗣 } \\ \text { 同 } & \text { 井 } & \text { 上幸 } & \text { 次 }\end{array}$

\section{主論文}

Assessment of real-time polymerase chain reaction detection of Acanthamoeba and prognosis determinants of Acanthamoeba keratitis

(Real-time polymerase chain reactionによるアカントアメーバの検出とアカントアメー バ角膜炎の予後決定因子の評価）

（著者：池田欣史、宮崎大、矢倉慶子、川口亜佐子、石倉涼子、井上幸次、水戸毅、 白石敦、大橋裕一、檜垣史郎、板橋幹城、福田昌彦、下村嘉一、八木田健司） 平成24年 0 phthalmology 掲載予定 


\section{学 位 論 文 要 旨}

Assessment of real-time polymerase chain reaction detection of Acanthamoeba and prognosis determinants of Acanthamoeba keratitis

(Real-time polymerase chain reactionによるアカントアメーバの検出とアカントアメー バ角膜炎の予後決定因子の評価）

アカントアメーバ角膜炎は多彩な臨床像を呈し、特効薬がないなど、診断・治療が難し く、視力予後不良な疾患である。そのため早期診断・治療の重要性が言われている。しか し、従来アカントアメーバの診断方法は正確性に乏しく、現在最も効果的な診断方法であ る角膜擦過物のCalcofluorやFungiflora Y 染色でも、擦過場所や染色により偽陰性を生 じることもあり、未だに十分ではない。また培養や検鏡では治療経過に伴うアカントアメ 一バ数の減少を判定して、治療効果を判定することは困難である。そのため、アカントア メーバの鋭敏な定量分析方法が望まれていた。

一方、アカントアメーバは細菌を領食して増殖するため、アカントアメーバ角膜炎の成 立過程で細菌が関与してくる可能性が考えられる。しかし、アカントアメーバ角膜炎にお いて病巣部における細菌の関与について検討した報告はない。

そこで本研究では、アカントアメーバの定量分析方法としてreal-time PCR法を構築し、 その感度・特異性を検討するとともに、アカントアメーバ角膜炎におけるアカントアメー バと細菌のDNAコピー数の相関関係を検索し、合わせて予後不良となる因子を統計学的に検 討した。

\section{方 法}

2006年1月より2010年12月までに鳥取大学、近畿大学、愛媛大学にて診断されたアカント アメーバ角膜炎および細菌性角膜炎を含む感染性角膜炎103例104眼を対象とした。アカン

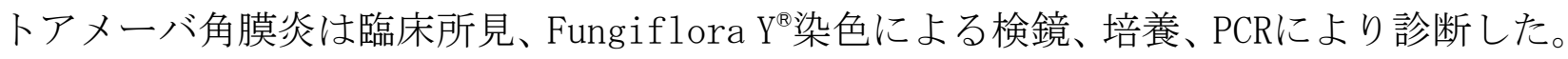
Real-time PCRはアカントアメーバでは18S rDNA領域を特異的に認識するプライマーと TaqMan probeを用い、細菌ではuniversal probeと16S rDNAのプライマーを用いて構築し、 アカントアメーバ角膜炎の予後不良となる危険因子の検索をロジスティック解析により評 価した。 


\section{結 果}

103例（男性49例、女性54例、平均年齢48.2 2 2. 歳）のうちアカントアメーバ角膜炎は 28例29眼（男性11例、女性17例、平均年齢26.4土1.7歳）で、27例（96.4\%）はコンタクト レンズ装用者であった。Real-time PCRによるDNAコピー数は検鏡によるアメーバ栄養体数

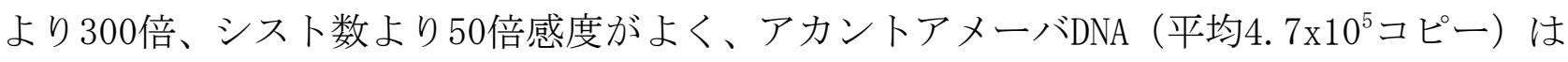
29眼中 25 眼 $(86.2 \%)$ に認められた。一方、Fungiflora Y 染色ではシストが26眼中20眼

（76.9\%）、培養は22眼中12眼（54.5\%）で陽性であった。細菌性角膜炎（75例）ではア カントアメーバDNAは認められなかった。また、細菌DNAは細菌性角膜炎75例中55例で検出

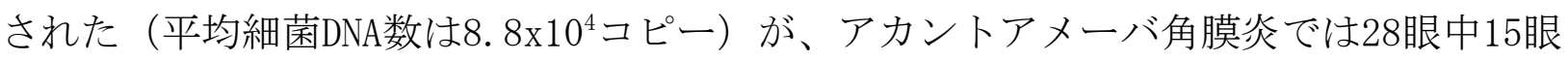

(53.6\%) で検出され、平均 $5.8 \times 10^{2}$ コピーと細菌性角膜炎の $1 / 100$ 以下であった。

初診時のアメーバコピー数はアカントアメーバ角膜炎の病期（重症度）と有意な相関が あり、さらには初診時視力とも有意に相関してした。しかし、細菌コピー数にはこれらと の相関は認められなかった。またアメーバコピー数とステロイドの使用やコンタクトレン ズ装用とは相関はなかった。視力予後良好なアカントアメーバ角膜炎では治療開始1ヶ月後 にコピー数が $90 \%$ 以上減少する割合が $100 \%$ であったが、視力予後不良な場合は $28.6 \%$ あ つた。視力予後不良と初診時の病期およびアメーバコピー数に有意な関連が見られた。ま た、治療に伴いコピー数が減少しない（1 ケ月で $90 \%$ 以下の減少）ことと初診時の病期が 有意に関連していた。なお細菌コピー数はこれらと有意に関連する因子ではなかった。

\section{考 察}

Real-time PCRは感度が高く、アカントアメーバを定量的かつ比較的迅速に測定できるた め、アカントアメーバ角膜炎の診断および治療効果判定に有用である。アカントアメーバ のコピー数は病期の進行と関連があり、初診時のアカントアメーバ角膜炎の病期（重症度） とコピー数が予後不良決定因子となるため、早期に診断し、治療を開始することの重要性 が明確となった。しかし、サンプル量や採取箇所により検鏡陽性でも、real-time PCRは陰 性となる場合が時に認められた。また個々の症例では臨床所見は重症であっても、コピー 数が少ない症例や治療に伴いコピー数が減少する場合があり、このような症例ではアメー バの量ではなく、強い免疫反応が臨床所見を悪化させていると考えられた。

\section{結 論}

Real-time PCRは感度・特異度が高く、臨床的に有用である。アカントアメーバ角膜炎の 初診時のアカントアメーバコピー数と角膜炎の重症度は視力予後不良決定因子である。 